\title{
GENIUS LOCI IN WOT BATU
}

\author{
${ }^{1}$ Khairi Ilman Chandra. ${ }^{2}$ Caecilia S. Wijayaputri, S.T., M.T. \\ ${ }^{1}$ Student in the Bachelor's (S-1) Study Program in Architecture \\ at Parahyangan Catholic University \\ ${ }^{2}$ Senior lecturer in the Bachelor's (S-1) Study Program in Architecture \\ at Parahyangan Catholic University
}

\begin{abstract}
In a modern environment, the existence of genius loci is starting to become rare. Places seem to lose their defining characteristics and this diminishes people's experience with them. In 2015, Sunaryo succeeded in building Wot Batu as a place that can exemplify a "man-made place" created in "modern" times that can showcase the existence of a genius loci. Therefore, this research discusses the factors that contribute to the emergence of genius loci and how it emerged in Wot Batu.

This research employs a descriptive-qualitative approach. The researcher analyzes theories that are related to definitions of, factors that constitute place, and types of genius loci, which are then utilized to provide an observation of the object. The data that is gathered consist of organizations of spatial structure and articulation of concrete properties. In addition, the researcher also interviewed Sunaryo Sutono about the background of Wot Batu.

The researcher identifies and classifies said data in a table of factors that constitute place which are then summarized to serve as a basis for explaining the genius loci that is established in Wot Batu.

In Wot Batu, the creator's strong intent to express spiritual meanings is accomplished in a specific way. The complexity of that spiritual understanding is manifested in its spatial structures and concrete properties that are impressively detailed. The ideas and personal life experiences that were once only found in Sunaryo Sutono's mind are brought into the world as a very specific place, and those things eventually coalesce into a totality and form genius loci that is meaningful to its user.
\end{abstract}

Key Words: genius loci, Wot Batu, Sunaryo, Ciburial Bandung

\section{GENIUS LOCI PADA WOT BATU}

\author{
${ }^{1}$ Khairi Ilman Chandra. ${ }^{2}$ Caecilia S. Wijayaputri, S.T., M.T. \\ ${ }^{1}$ Mahasiswi S1 Program Studi Arsitektur Universitas Katolik Parahyangan \\ ${ }^{2}$ Dosen Pembimbing S1 Program Studi Arsitektur Universitas Katolik Parahyangan
}

\begin{abstract}
Abstrak- Pada lingkungan modern keberadaan genius loci mulai sulit ditemukan, tempat-tempat dirasa kehilangan karakteristik khusus sehingga pengalaman manusia akan tempat menjadi lemah. Pada tahun 2015, Sunaryo berhasil membangun Wot Batu yang dapat menjadi contoh dari "tempat buatan manusia" yang diciptakan pada zaman "modern" yang mampu menunjukkan keberadaan genius loci. Karena itu, penelitian ini membahas faktor-faktor apa sajakah yang membantu pembentukan genius loci dan juga bagaimanakah genius loci yang terbentuk pada Wot Batu.

Jenis penelitian ini adalah deskriptif kualitatif. Peneliti menelaah teori terkait dengan definisi, faktorfaktor pembentuk tempat, dan jenis genius loci, kemudian teori tersebut dipakai untuk mengobservasi objek. Data-data yang diteliti mencakup organisasi struktur spasial dan artikulasi properti konkret. Selain itu, peneliti juga mewawancarai Sunaryo Sutono untuk mengetahui latar belakang Wot Batu.

Peneliti mengidentifikasi dan mengklasifikasikan data-data ke dalam tabel faktor-faktor pembentuk tempat kemudian kesimpulan yang didapat dijadikan landasan untuk menjelaskan genius loci yang terbentuk pada Wot Batu.

Pada Wot Batu intensi pencipta yang kuat untuk menceritakan makna-makna spiritual terwujudkan melalui pendekatan yang sedemikian rupa. Kompleksitas akan pemahaman spiritual itu sendiri nampak tertuang
\end{abstract}

\footnotetext{
${ }^{1}$ Corresponding Author: ilmanchandraaa@gmail.com
} 
menjadi struktur spasial dan properti konkret yang sangat terperinci. Ide-ide dan pemahaman hidup personal yang pada awalnya tinggal pada alam pikiran Sunaryo Sutono dihadirkan ke alam dunia menjadi tempat yang sangat spesifik, dan pada akhirnya semua hal tersebut bergabung menjadi suatu totalitas dan membentuk genius loci yang bermakna bagi penggunanya.

Kata Kunci: genius loci, Wot Batu, Sunaryo, Ciburial Bandung

\section{PENDAHULUAN}

Sebelum globalisasi, genius loci lebih mudah untuk ditemukan karena keterbatasan wawasan menjadikan masyarakat lebih menghargai segala hal yang terjadi di lingkungannya. Fenomena yang ada di sekitar menjadi sumber utama untuk bertindak. Cerminan dari hal tersebut dapat dilihat pada bangunan tradisional. Setiap aspek yang terrancang pada bangunan tradisional berasal dari hasil penanggapan terhadap lingkungan. Mulai dari material yang menunjukkan ketersediaan sumber daya alam; bentuk dan fitur-fitur bangunan yang menanggapi konteks iklim, konstruksi yang menunjukkan wawasan teknologi, hingga ornamentasi khusus yang melambangkan suatu kebudayaan yang ada.

Setelah globalisasi, genius loci lebih sulit untuk ditemukan karena paparan pengetahuan yang sudah mendunia kadang menjadikan permasalahan dan fenomena yang ada menjadi milik bersama. Adanya sumber pengetahuan yang tidak terbatas memberi peluang kepada peradaban manusia untuk berkembang dengan cepat. Lingkungan yang ada merupakan hasil dari ikatan yang kuat dari budaya manusia dan tempat. Pada masa kini, terjadi suatu fenomena di mana asimilasi budaya-budaya lama telah membentuk suatu kelompok besar kebudayaan modern. Karena demikian, lingkungan yang ada sekarang mencerminkan bentukan baru dengan karakteristik dan makna yang baru pula.

Norberg-Schulz berkata bahwa pada arsitektur vernakular genius loci seharusnya menanggapi lingkungan alami, sedangkan pada arsitektur kota (modern), genius loci seharusnya mengandung kelokalan tetapi juga mampu menanggapi hal-hal umum ${ }^{2}$. Pernyataan tersebut dapat dikaitkan dengan jawaban dari pertanyaan mengapa orang-orang pada umumnya selalu mengasosiasikan genius loci dengan contoh-contoh yang seringkali merupakan arsitektur vernakular. Hal tersebut dikarenakan arsitektur vernakular memang selalu menunjukkan karakter yang kuat sedangkan arsitektur modern seringkali menunjukkan karakter yang lemah (misalkan dengan menggunakan tren-tren tertentu atau material yang lemah identitas lokal seperti: kaca, baja, dsb.) sehingga menjadikan genius loci-nya sulit dirasakan. Tiap tempat (alami ataupun buatan) yang baik seharusnya mampu menunjukkan genius loci, baik dari tempat dalam skala besar seperti kota, hingga dalam skala kecil sekalipun seperti bangunan sehingga dapat memberi pengalaman yang berbeda.

Pada tahun 2015, seorang maestro seni Indonesia bernama Sunaryo Sutono berhasil menyelesaikan proyeknya yang bernama Wot Batu. Karya tersebut merupakan museum berkonsep ruang terbuka yang memberikan pesan mengenai makna-makna kehidupan melalui proses sekuensial. Wot Batu adalah sintesis konfigurasi energi dari perjalanan spiritual Sunaryo yang tersusun secara harmonis dan terkonsep. Di dalam konsepnya, Wot Batu merupakan sebuah 'jembatan' yang menjadi penyeimbang antara keberadaan jiwa manusia, manifestasi elemen fisik, dan dimensi waktu yang melingkupnya.

Karya-karya seni Sunaryo selalu bercerita tentang keadaan sosial, lingkungan, spiritualitas, dan tujuan. Wot Batu merupakan hasil dari konfigurasi spasial yang harmonis antara instalasi seni pahat, rancangan lanskap, dan arsitektur yang lahir dari intuisi seorang seniman. Wot Batu dijadikan objek penelitian karena merupakan bangunan yang diciptakan

\footnotetext{
${ }^{2}$ Norberg-Schulz, Christian. 1979. Genius Loci: Towards a phenomenology of Architecture. New York: Rizolli.
} 
pada masa modern namun mampu menunjukkan kepekaan yang kuat terhadap faktor utama pembentuk genius loci yaitu pada organisasi ruang dan artikulasi karakter.

Karena hal-hal tersebut maka penelitian ini bertujuan untuk mengetahui dan mempelajari faktor-faktor yang membantu pembentukan genius loci pada Wot Batu dan untuk mengetahui dan mempelajari genius loci pada Wot Batu.

Penelitian ini diharapkan dapat bermanfaat untuk bahan pembelajaran bagi penulis, wawasan bagi para pembaca, kontribusi literatur dalam bidang arsitektur yang membahas tentang genius loci, dan sebagai bahan studi mengenai genius loci dan makna-makna tempat untuk pihak-pihak yang bersangkutan

Tempat penelitian berada di Kota Bandung tepatnya pada Wot Batu milik bapak Sunaryo Sutono yang berada di Jalan Bukit Pakar Timur No. 98, Bandung. Sedangkan waktu penelitian berlangsung dari Februari 2018 hingga Mei 2018.

\section{KAJIAN TEORI}

Manusia dapat mempengaruhi dan mengubah lingkungan, begitu pula sebaliknya, lingkungan juga dapat mempengaruhi manusia. Selain memahami sisi praktikal / fungsional dari lingkungan fisik, manusia juga membutuhkan pemahaman yang lebih filosofis. Manusia tidak bisa mendapatkan suatu pijakan melalui pemahaman saintifik saja ${ }^{3}$, manusia membutuhkan simbol yaitu karya seni yang merepresentasikan keadaan hidup (lifesituation $)^{4}$.

Dalam konkretisasi seni, suatu makna (hal yang abstrak) diubah dan disintesiskan menjadi objek nyata (fisik), manusia dalam kehidupannya memiliki kebutuhan dasar untuk merasakan lingkungannya sebagai sesuatu yang bermakna, maka dari itu objek seni ada untuk menyimpan dan menyampaikan kembali makna dirinya ${ }^{5}$.

Kebutuhan manusia untuk menghuni dikonkretkan dan dimanifestasikan menjadi tempat, dan identitas manusia tersebut bergantung kepada keterlibatannya dengan tempat (belonging to places) ${ }^{6}$. Dari pernyataan tersebut dapat dimengerti bahwa abstraksi dari konsep "menghuni" disintesiskan menjadi objek fisik, yang kemudian menjadi gambaran tentang identitas manusia yang menggunakannya. Teori tersebut dapat dimaknai secara siklik karena konkretisasi tempat berasal dari intensi manusia untuk menghuni, yang pada hasilnya terdapat pula manifestasi dari identitas manusia yang membentuknya, namun tempat tersebut juga dapat berperan untuk mendefinisikan dan mempengaruhi penggunanya ${ }^{7}$.

"Dunia kita sehari-hari terdiri dari fenomena konkret, tetapi juga terdiri dari fenomena yang tak berwujud seperti perasaan"8. Hal-hal yang selalu disadari terlebih dahulu adalah hal-hal fisik, sedangkan yang non-fisik baru disadari kemudian atau bahkan tidak disadari perannya sama sekali. Padahal, hal-hal yang bersifat non-fisik itu juga merupakan fenomena yang turut berperan dalam pembentukan lingkungan fisik.

Yi Fu Tuan mengatakan bahwa pengertian dari "tempat" umumnya adalah posisi seseorang dalam masyarakat (berhubungan dengan status dalam keilmuan sosiologi), dan lokasi spasial (berhubungan dengan lokasi dalam ilmu geografi). Berikutnya Yi Fu Tuan mengutip gagasan dari Marjorie Grene bahwa makna utama dari "tempat" adalah posisi seorang dalam masyarakat. Dari gagasan tersebut dapat ditarik contoh: seorang pimpinan

\footnotetext{
${ }^{3}$ Ibid., halaman 2.

${ }^{4}$ Ibid., halaman 2.

${ }^{5}$ Ibid., halaman 2.

${ }^{6}$ Ibid., halaman 2.

${ }^{7}$ Ibid., halaman 2.

${ }^{8}$ Ibid., halaman 2.
} 
dalam perusahaan, dengan karyawannya akan di lokasikan pada tempat yang berbeda, maka status yang ada melahirkan penentuan lokasi spasial, namun tidak berlaku secara terbalik. "Pertama-tama orang-orang didefinisikan oleh posisi dalam masyarakat, kemudian diikuti oleh karakteristik gaya hidup. Gaya hidup secara khusus dapat meliputi makanan, pakaian, hingga tempat hidup dan bekerja." . Dalam pengalaman sehari-hari, tindakan yang berbeda membutuhkan lingkungan yang berbeda pula, bahkan kegiatan mendasar seperti tidur dan makan membutuhkan tempat yang berbeda ${ }^{10}$.

Tipe tempat dapat dikategorikan sebagai "public symbol" dan "fields of care". Public symbol memiliki imageability yang lebih kuat karena kemampuannya untuk menangkap perhatian visual yang lebih baik. Sedangkan fields of care memiliki imageability yang lebih rendah, keberadaannya tidak begitu mencolok, dan memang pada umumnya tidak bertujuan untuk menampilkan suatu citra dan mencari perhatian dari luar. Public symbols mampu menarik perhatian dan kekaguman, sedangkan fields of care membangkitkan afeksi ${ }^{11}$. Namun, tidak menutup kemungkinan bahwa suatu tempat dapat dinyatakan sebagai simbol publik dan juga fields of care.

Struktur dari tempat terdiri dari "ruang" dan "karakter". Ruang berhubungan dengan pengorganisasian struktur spasial yang membantu manusia untuk dapat mengorientasikan dirinya atau untuk mengetahui di mana ia berada. Sedangkan, karakter berhubungan dengan pengartikulasian properti konkret lingkungan yang membantu manusia untuk dapat mengidentifikasi dirinya atau untuk mengetahui bagaimanakah tempat yang ia alami.

Norberg-Schulz mengatakan bahwa genius loci pada tempat buatan manusia bergantung pada bagaimana ruang dan karakternya, yaitu pada organisasi dan artikulasinya ${ }^{12}$. Dari pernyataan tersebut dapat dimengerti bahwa konsep ruang didefinisikan oleh organisasinya, dan karakter yang ada diekspresikan dengan artikulasi.

Hal-hal terkait "ruang" membahas tentang perbatasan (boundary); penutup (enclosure); bukaan (openings); landmark; pusat (centre) dan jalur (path); wilayah (domain); dan konfigurasi pola dasar (archetypal configuration). Sedangkan hal-hal terkait "karakter" membahas tentang artikulasi bentuk, material, tekstur, warna, dan susunan.

Dari akhir sub-bab dalam buku Norberg-Schulz yang membahas tentang genius loci pada tempat buatan manusia. Ia mengkategorikan tempat berdasar ciri-cirinya yang khas dan mencoba memberi gambaran sifat atau atmosfer yang tercipta. Norberg-Schulz memberi penjelasan mengenai pemahaman umum untuk menafsirkan genius loci melalui beberapa kategori, yaitu arsitektur romantik, arsitektur kosmik, arsitektur klasik, dan arsitektur kompleks $^{13}$.

\footnotetext{
${ }^{9}$ Tuan, Yi Fu. 1977. Space and Place. Minessota: University of Minessota Press.

${ }^{10}$ Christian Norberg-Schulz, Op. Cit., halaman 2.

${ }^{11} \mathrm{Yi} \mathrm{Fu}$ Tuan, Op. Cit., halaman 3.

${ }^{12}$ Christian Norberg-Schulz, Op. Cit., halaman 2.

${ }^{13}$ Ibid., halaman 2.
} 


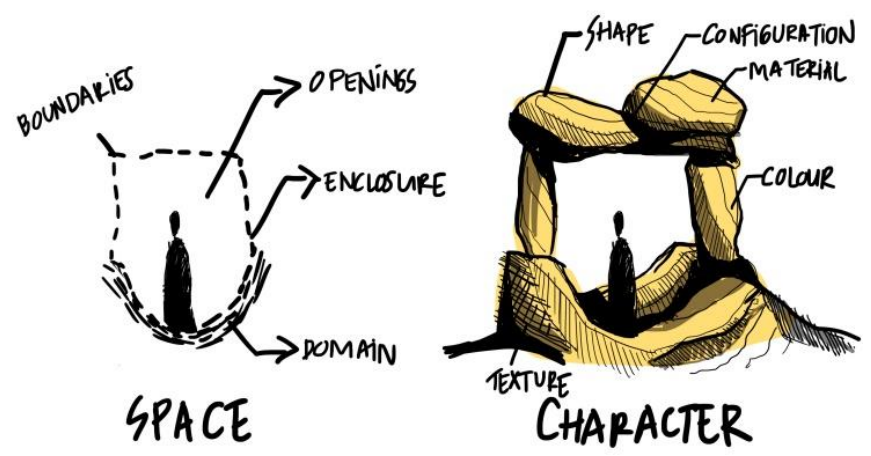

Figur 1. Struktur Tempat

\section{METODA PENELITIAN}

Jenis Penelitian. Jenis penelitian yang dilakukan menggunakan pendekatan deskriptif kualitatif. Peneliti melakukan telaah literatur terkait dengan genius loci dan faktor-faktor pembentuknya yang kemudian digunakan sebagai acuan untuk mengobservasi objek, lalu data-data hasil analisis objek (yang sifatnya kualitatif) distrukturkan kembali dan dibahas secara naratif.

Jenis-jenis Data Wot Batu yang dikumpulkan mencakup:

a. Data primer: meliputi struktur spasial (ruang) dan properti konkret (karakter) pada Wot Batu, latar belakang pencipta Wot Batu, latar belakang Wot Batu (sejarah, konsep, dsb.) yang didapat melalui observasi pribadi dan wawancara; juga

b. Data sekunder: meliputi ikhtisar mengenai Wot Batu dan penciptanya, juga denah Wot Batu yang didapat dari katalog Wot Batu, dan telaah literatur Sunaryo: Jagat Tanpa Sekat, dan WOT BATU: Sunaryo's Stones Bridge: a Passage through Wood, Water, Wind, and Soul.

Teknik Pengumpulan Data. Terdapat beberapa teknik yang dipakai dalam pengumpulan data, yaitu:

a. Observasi langsung: peneliti terlibat langsung di dalam objek studi, lalu mengumpulkan data-data dengan mengandalkan kepekaan pribadi.

b. Wawancara terstruktur: dalam wawancara ini, daftar pertanyaan sudah dipersiapkan, lalu didokumentasikan dengan pencatatan, perekaman gambar dan perekaman suara.

c. Studi dokumen: melakukan analisis terhadap dokumen primer yang diberikan pihak pengelola, ditambah dengan dokumen sekunder yang juga membahas mengenai objek studi. Dokumen yang dimaksud meliputi dokumen fisik dan digital; 3D dan 2D seperti gambar kerja, sketsa konsep, model, dsb.

Tahapan Pengumpulan Data. tahapan-tahapan yang perlu dilewati dalam proses pengumpulan data, yaitu:

a. Kunjungan pertama: mengobservasi aspek yang berkaitan dengan fisik spasial serta pengalaman sensori, lalu mendokumentasikannya sebagai catatan-catatan penelitian pribadi, 
b. Kunjungan kedua: wawancara terstruktur dengan pak Sunaryo Sutono membahas Wot Batu meliputi konsep, latar belakang, tanggapan pribadi tentang genius loci (genius loci). Lalu diakhiri dengan pengumpulan data-data digital 2D (gambargambar kerja, sketsa konsep), model 3D (bila ada), video dan foto-foto dokumentasi (perencanaan, pembangunan (awal - akhir)) dari pihak pengelola atau pak Sunaryo.

c. Kunjungan ketiga: observasi dan dokumentasi untuk melengkapi data-data yang terlewatkan.

Teknik Analisis Data. Terdapat beberapa cara yang peneliti lakukan dalam proses menganalisis data, yaitu:

a. Peneliti mengidentifikasi variabel-variabel data yang sudah didapat dari hasil observasi pribadi dengan data sekunder yaitu denah, lalu mengklasifikasikannya ke dalam tabel elemen-elemen boundaries yaitu dinding, lantai, dan langit-langit serta enclosure dan openings terkait teori faktor-faktor pembentuk tempat (ruang dan karakter);

b. Peneliti mengidentifikasi data-data hasil wawancara dengan responden berhubungan dengan latar belakang tempat, faktor-faktor pembentuknya (ruang dan karakter), dan pemaknaan pribadi dari pencipta Wot Batu;

c. Peneliti mencari keterkaitan dari data-data hasil observasi pribadi dan wawancara, kemudian menghubungkannya (contohnya: menghubungkan struktur spasial dan properti konkret yang ada dengan sejarah atau latar belakang objek);

d. Peneliti membandingkan dan mencari kesamaan antara bukti-bukti yang didapat dengan ciri-ciri dari teori klasifikasi geniusloci;

e. Peneliti memberi sketsa-sketsa atau coretan di atas foto untuk mempertegas hasil analisis.

Objek. Wot Batu milik Sunaryo berada di Jalan Bukit Pakar Timur No. 98, Bandung, Jawa Barat, Indonesia. Terletak pada area sub-urban, daerah sekitar tapak umumnya adalah permukiman masyarakat perekonomian tingkat menengah hingga tingkat atas, dan banyak terdapat café seiring jalan Bukit Pakar Timur, terdapat Selasar Sunaryo Art Space yang juga merupakan bangunan milik pak Sunaryo yang terletak 100 meter ke arah atas (Timur Laut) dari Wot Batu.

Area sekeliling tapak tergolong berkepadatan rendah, sisi sebrang jalur masuk ke bangunan yaitu arah Barat Laut dan sisi kiri tapak yaitu arah Timur Laut terdapat lahan kosong tertutup vegetasi yang cukup luas; bagian Barat Daya dihimpit oleh Jl. Bukit Pakar Timur V yang berikutnya juga terdapat lahan kosong yang ditutupi vegetasi; dan di Bagian Tenggara terdapat perumahan. Kontur dalam tapak sudah diratakan namun pada kondisi eksisting kontur sekitar tapak tergolong curam; elevasi menurun ke arah Tenggara.

Lokasi tapak yang berada di dataran tinggi dan dikelilingi oleh lahan yang relatif terbuka menjadikan pemandangan dari dalam tapak dapat secara leluasa dipandang. Dilengkapi dengan keadaan lingkungan yang masih asri menambahkan nilai lebih pada aspek visual. Fungsi area yang didominasi perumahan mendukung tapak untuk tetap hening, sumber bising umumnya hanya berasal dari satu sisi yaitu dari area Jl. Bukit Pakar Timur (jalan utama untuk mengakses tapak). Aspek Termal pada tapak juga sangat baik karena banyaknya vegetasi di dalam ataupun disekeliling tapak, ditambah lokasi geografisnya yang berada pada dataran tinggi dan jauh dari pusat aktivitas kota.

Dari katalog yang diberikan kepada setiap pengunjung dicantumkan bahwa: 
"Wot Batu merupakan museum ruang terbuka berbentuk taman, yang disajikan secara sekuensial mengenai konfigurasi energi yang muncul dari perjalanan Spiritual Sunaryo, tapak yang dipakai memiliki luas total $2000 \mathrm{~m}^{2}$, didalamnya terdapat $135+$ 1 batu yang ditanam secara harmonis dan terkonsep. Sunaryo menciptakan Wot Batu sebagai "jembatan" spiritual: untuk menjadi penyeimbang antara jiwa manusia dengan manifestasi fisik dari hidup, juga untuk menjadi penghubung antara empat elemen alam. Dalam Wot Batu, bumi, api, air, dan angin berkomunikasi dengan sesama dalam harmoni. Wot Batu membawa ide-ide dari ruang dan waktu, juga kesadaran akan eksistensi manusia dalam dimensi alam yang tak terbatas."

Wot Batu diciptakan sebagai wadah perenungan hidup. Material-material yang digunakan didalamnya menggunakan batu agar bisa bertahan dalam jangka waktu lama, pahatan-pahatan menggunakan peralatan tenaga listrik untuk menunjukkan teknologi zaman, di salah satu instalasi juga diukirkan sidik jari raksasa (yang merupakan sidik jari pak Sunaryo) untuk menunjukkan zaman yang telah mengenal identitas. Walau material yang digunakan adalah batu-batu raksasa, beliau tidak ingin pengamatnya menganggap bahwa Wot Batu adalah taman batu pra-sejarah, maka dari itu beliau menyajikan karya batu dengan tanda-tanda dari teknik seni modern.

Pak Sunaryo mengatakan bahwa salah satu konsep dari Wot Batu adalah harmoni atau keseimbangan, seperti halnya dalam kehidupan yang selalu ada positif-negatif, karena itulah instalasi Wot Batu saling berpasang-pasangan. Sebagai contoh, terdapat batu Abah Ambu (bapak dan ibu) yang tentunya melambangkan laki-laki dan perempuan; ada pula batu yang diletakkan tiduran atau horizontal, dan batu yang didirikan menjulang tinggi atau vertikal; ada batu yang ditenggelamkan, ada yang diletakkan dengan kesan melayang; dan banyak lagi objek-objek yang mengandung makna keseimbangan tersebut. Lalu, konsep lain dari Wot Batu adalah akumulasi dari perjalanan spiritual Sunaryo Sutono, yang pada akhirnya terpecah menjadi beberapa instalasi yang menyimpan potongan-potongan makna dari keseluruhan pesan spiritual tersebut.

"Wot Batu mungkin dapat bertahan hingga 100 hingga 200 tahun", ucap pak Sunaryo, ia mengatakan bahwa Wot Batu ingin memberikan pesan kepada generasi anak cucu manusia bahwa tempat tersebut bukan merupakan wujud persembahan kepada dewa-dewa, tetapi adalah karya seni sebagai visualisasi dari seorang seniman.

Beliau melanjutkan perbincangan dan berkata, "Bandung disebut-sebut sebagai kota kreatif dan kota wisata, tetapi orang-orang datang hanya untuk ke café, mall, outlet, dan kunjungan lainnya yang bersifat konsumerisme". Fenomena tersebut adalah salah satu pemicu didirikannya Wot Batu, "maka dari hal tersebut maka saya rasa tidaklah berlebihan jika saya ingin memberi penanda zaman, catatan kecil sebuah peradaban", ucap Beliau. Pak Sunaryo menambahkan bahwa, Ia ingin pengunjung yang menikmati Wot Batu dapat sejenak melupakan keseharian.

Pada tahun 1998, beliau mengadakan pameran "Titik Nadir", suatu momen kekecewaan mendalam yang dirasakannya. Ia berpikir "berkesenian itu untuk apa?", yang pada akhirnya mantan dosen Seni Rupa ITB ini mendapatkan jawaban bahwa "berkesenian berguna untuk menyampaikan suatu pesan kepada orang lain", lalu dihubungkan ke Wot Batu ia berkata bahwa "Wot Batu adalah kurikulum untuk manusia yang akan datang". Pada periode-periode lalu karya pak Sunaryo sering membahas tentang lingkungan, yang mencakupi fenomena sosial, budaya, ekonomi, dst. (dinamis). Namun telah datang pemahaman atau prinsip baru untuk membuat seni yang "tidak sesaat".

Dari wawancara dengan bapak Sunaryo Sutono dijelaskan bahwa salah satu tahapan awal saat merancang Wot Batu ini adalah dengan menciptakan suatu garis sumbu yang 
memotong dari Timur ke Barat. Kemudian dilakukan trial and error untuk mendirikan instalasi-instalasi batu. Beliau menjelaskan bahwa hasil yang tercipta kira-kira 40\% berdasarkan ide yang sudah direncanakan dan 60\% muncul sejalan dengan proses pembangunan. Dalam proses pembangunan Wot Batu, objek yang tercipta dalam satu tahapan menjadi parameter bagi terciptanya objek pada tahapan berikutnya. Objek-objek ditata dengan mengikuti perasaan atau intuisi beliau dengan tujuan untuk mencari harmoni atau keseimbangan.

Kolam membagi ruang kanan dan ruang kiri. Wot Batu yang memiliki konsep "sekuensial" menjadikan konfigurasi jalur sirkulasi yang linear. Tetapi keseluruhan ruang pada tapak yang bentuknya persegi, ditambah dengan adanya kolam di bagian tengah menunjukkan organisasi spasial terpusat. Dari wawancara didapatkan bahwa Lawang Batu adalah instalasi pusat yang pemegang konsep dalam Wot Batu. Lawang Batu membagi daerah yang mengandung makna "dunia" dan "akhirat" yang pada denah merupakan suatu bidang extension atau adisi berupa kolam. Dari wawancara didapat penjelasan bahwa Lawang batu, Batu Mandala, dan Batu Angin sebagai "pemegang ruang".

(1) Lawang Batu sebagai pemegang konsep utama Wot Batu menceritakan tentang "alam kehidupan" yang terbagi oleh kolam antara daerah kiri dan kanan dilanjutkan dengan "alam akhirat" pada instalasi Batu Air. (2) Batu Mandala sebagai pemegang elemen horizontal. (3) Batu Angin sebagai batu tertinggi berperan sebagai pemegang elemen vertikal yang juga menjadi "harmoni" dari keberadaan Batu Mandala. Pak Sunaryo juga mengatakan bahwa tanpa adanya Batu Angin mungkin Wot Batu akan menjadi seperti taman biasa.

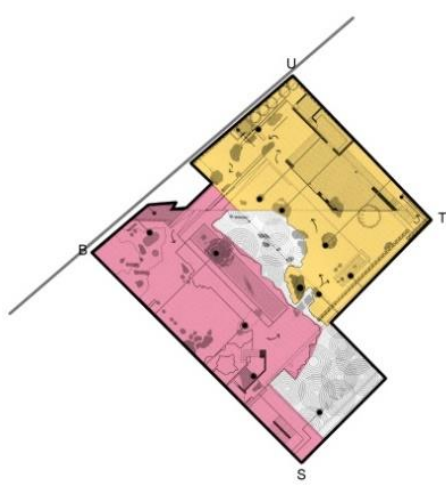

Figur 2. Analogi otak kanan dan kiri

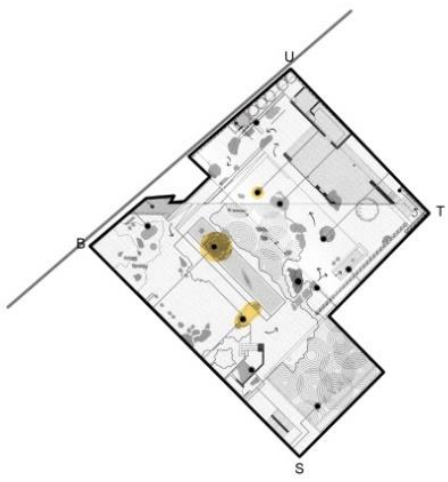

Figur 4. Instalasi pemegang ruang

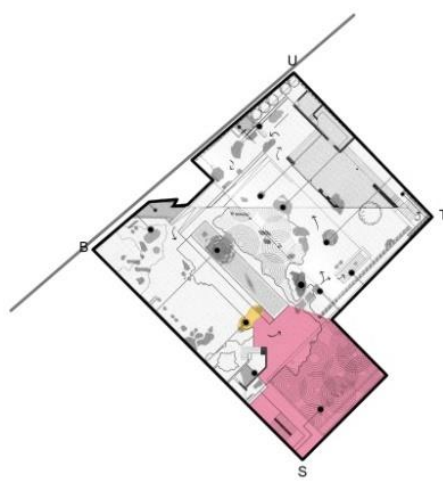

Figur 3. Analogi alam dunia dan alam akhirat

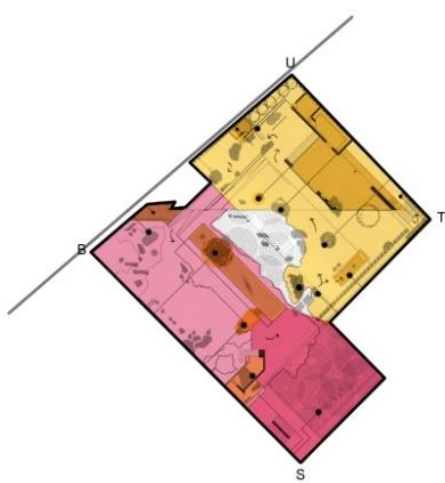

Figur 5. Pembagian ruang 


\section{ANALISA}

Wot Batu sebagai Tempat. Dalam pembahasan mengenai "Wot Batu sebagai tempat" dapat disimpulkan bahwa Wot Batu adalah bangunan individu dengan keunikan kuat yang berasal dari proses konkretisasi pengalaman spiritualitas Sunaryo Sutono dan terpisah dari langgam objek-objek umum dengan pemahaman komunal.

Walaupun sudah jelas bahwa Wot Batu adalah tempat, telah dibahas juga pemahaman-pemahaman tentang fenomena yang mendasari suatu tempat untuk pemahaman yang lebih mendalam. Wot Batu dapat dinyatakan sebagai tempat karena telah membuktikan pernyataan Norberg-Schulz bahwa "ruang" yang didalamnya terdapat "kehidupan" adalah "tempat". Lalu, jika dikaitkan dengan pernyataan Relph, Wot Batu juga merupakan objek yang mampu berdiri sendiri, memiliki lokasi tetap, dan memiliki fitur yang bertahan.

Berikutnya, terkait dengan pembahasan oleh Tuan: Wot Batu dapat dikategorikan sebagai jenis simbol publik sekaligus sebagai fields of care. Hal tersebut dikarenakan oleh imagibility Wot Batu yang kuat karena elemen-elemen konkretnya seperti boundaries, dan objek-objek seni yang monumental mampu memunculkan kekaguman, Namun, dapat juga dikatakan sebagai kategori fields of care karena Wot Batu memiliki tujuan untuk menyampaikan makna-makna spiritual dan hal-hal tersebut terkonkretisasikan menjadi komponen-komponen fisik yang mampu memberi stimulan sense of place untuk pengguna.

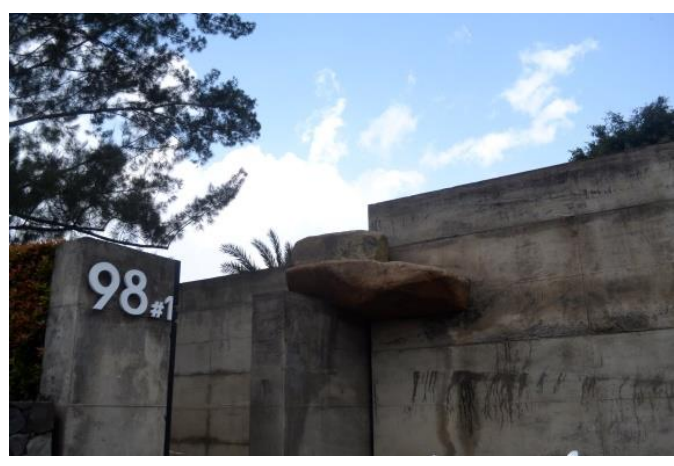

Figur 6. Wot Batu sebagai simbol publik

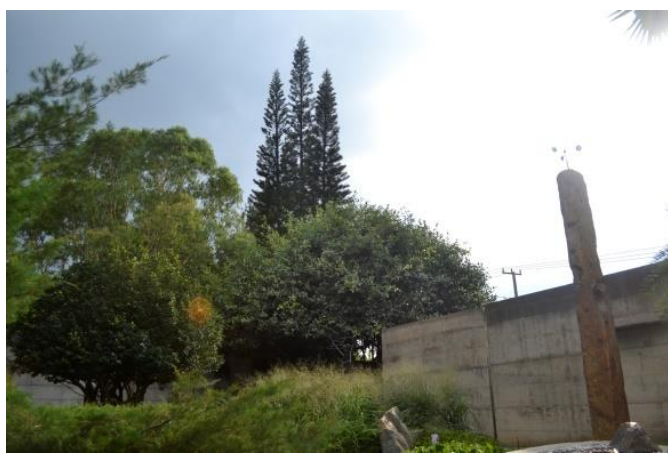

Figur 7. Wot Batu sebagai fields of care

Faktor Pembentuk Tempat Pada Wot Batu. Faktor-faktor tempat mengikuti buku "Genius Loci: Towards a Phenomenology of Architecture" ciptaan Norberg-Schulz terdiri dari "ruang" dan "karakter". Organisasi "struktur spasial" sebagai objek "orientasi" manusia didefinisikan oleh "properti konkret" sebagai objek "identifikasi" manusia dengan membahas artikulasi bentuk, material, tekstur, warna, dan susunan. Pada Wot Batu, objekobjek yang ditinjau adalah: boundaries utama yang melingkup tapak, dan boundaries dalam boundaries yaitu bangunan-bangunan yang ada dalam Wot Batu.

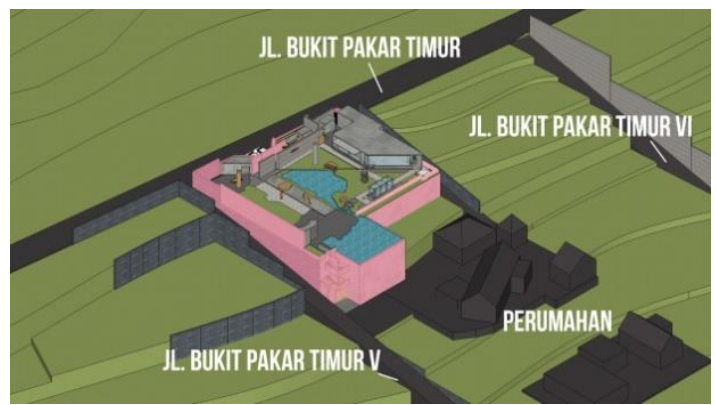

Figur 8. Boundaries utama

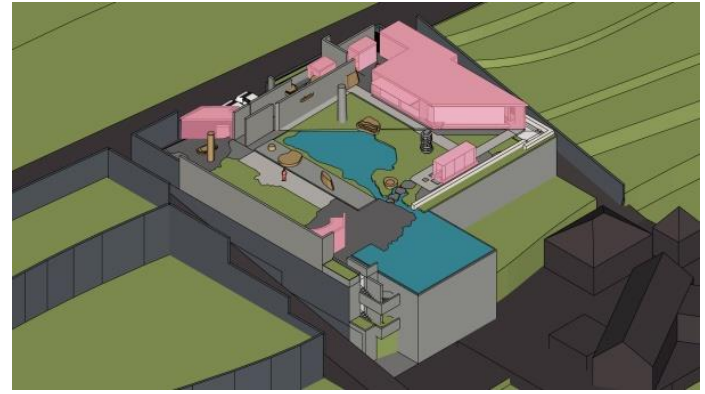

Figur 9. Boundaries within boundaries 


\section{Enclosure}

Perbatasan administratif Wot Batu yang memisahkan antara ruang luar dengan ruang dalam ditegaskan oleh dinding lateral dengan "material" batu kali lagadar, beton, dan batu kapur padalarang. Bentuk dindingnya geometris yaitu persegi panjang dan variasinya terdapat pada perubahan tinggi atau lebar. Dindingnya disusun mengikuti garis terluar tapak dan juga mengikuti arah-arah mata angin. Tekstur dan warna dindingnya mengikuti fitur-fitur alami dari material yang digunakan.

Boundaries within boundaries pada Wot Batu memiliki karakteristik yang berbeda antara yang satu dengan yang lainnya. Dari keenam objek yang dibahas (konter tiket, musholla, bangunan Batu Api, bangunan Batu Ruang, Bale Batu, dan bangunan Batu Waktu) tidak ada satupun yang berbentuk sama.

Bentuk pada objek-objek tersebut dibedakan oleh dimensi (lebar dan tinggi) dan memiliki kesamaan pada bentuk dasarnya yang geometris atau persegi panjang. Dinding-dindingnya disusun mengikuti arah-arah mata angin. Material dinding yang digunakan pada umumnya adalah beton dan kaca, namun pada dinding depan Musholla juga digunakan material lain yaitu granit Itali.

Tekstur yang ada pada dinding boundaries within boundaries bervariasi mengikuti materialnya, jika dikomparasikan dapat dikatakan terdapat tekstur sangat kasar (seperti pada bagian luar dinding granit Itali); kasar (seperti pada dinding beton); licin (seperti pada bagian dalam dinding granit Itali dan dinding kaca). Warna dinding-dinding pada umumnya mengikuti fitur-fitur alami dari material yang digunakan, namun juga terdapat variasi contohnya seperti permukaan luar dengan permukaan dalam dinding granit Itali pada musholla(kuning dengan abuabu), dan juga kaca trasparan pada Bale Batu dengan kaca transparankebiruan pada bangunan Batu Ruang.

\section{Openings}

Bukaan pada dinding utama Wot Batu berfungsi sebagai akses keluar--masuk pengguna (pintu) dan juga sebagai penghubung visual dengan lingkungan luar (jendela). Bukaan yang berfungsi sebagai pintu masuk diciptakan pada dinding depan (barat laut), dan bukaan yang berfungsi sebagai jendela diciptakan pada sisi timur laut dan tenggara. Bentuknya secara umum merupakan bentuk geometris persegi panjang, namun pada kasus seperti pada bukaan sisi tenggara bentuknya bisa dikatakan organik (karena batasan yang ambigu). Bukaan yang ada memiliki dimensi yang berbeda-beda: pintu-pintu memiliki dimensi yang kecil, sedangkan jendela memiliki dimensi yang sangat besar.

Pada boundaries within boundaries, bukaan pada umumnya memiliki bentuk dasar geometris dengan dimensi yang berbeda-beda kecuali pada Musholla yang memiliki sedikit adisi organik. Susunan atau perletakannya pada umumnya juga tidak ada yang sama (dalam artian: tidak diletakkan mengikuti posisi tertentu, misalkan rata kanan, rata tengah dsb.). ada yang terbuka sepenuhnya tanpa terbatasi material, ada pula yang 
terbuka dalam artian visual namun terbatasi oleh material kaca dengan warna transparan (Bale Batu) atau transparan-kebiruan (bangunan Batu Ruang).

\section{Enclosure}

Enclosure lantai Wot batu secara keseluruhan berbentuk persegi yang di adisi oleh bentuk persegi yang lebih kecil pada salah satu bagian sisi tenggaranya. Pada bagian dalam terdapat pula beberapa wilayah yang dapat dibedakan berdasarkan kemiripan atau kedekatan (proximity) teksturnya. Wilayah-wilayah yang ada memiliki bentuk yang berbedabeda. Susunannya sangat organik atau dapat juga disebut clustered. Material yang digunakan didominasi oleh batu sikat, beton, rumput, dan air. Tekstur dan warnanya bervariasi mengikuti material.

Dari wilayah-wilayah dan dinding yang ada tercipta pula Jalurjalur di antaranya yang terdidefinisi oleh material paving block, batu sikat, kerikil andesit, dan batu paving andesit. Jalur yang terbentuk mengikuti konsep Wot Batu untuk bercerita tentang pengalaman spiritual Sunaryo

Lantai Sutono melalui proses sekuensial, karena itu, pola jalurnya menjadi linear dan sirkular mengikuti sisi-sisi dan batas tapak.

Sebagai tambahan, instalasi-instalasi seni dan bangunan-bangunan kecil yang ada dapat dinyatakan sebagai landmark. Banyaknya landmark pada Wot Batu menjadikan wilayah-wilayahnya semakin spesifik sehingga mempermudah pengguna untuk mengidentifikasi.

\section{Openings}

Bukaan pada lantai dalam Wot Batu dimengerti sebagai penghubung ruang-atas dengan ruang-bawah. Hanya terdapat sedikit bukaan pada lantai Wot Batu yaitu pada sudut timur (menuju toilet), sudut selatan (menuju ruang staff), dan pada bangunan Batu Ruang. Bentuknya geometris, dan disusun secara paralel mengikuti batas dinding di sekitarnya.

\section{Enclosure}

Pada boundaries within boundaries Wot Batu, langit-langit dari keenam objek memiliki bentuk yang berbeda. Bentuknya geometris dan disusun mengikuti pola dasar dari permukaan lantai. Variasi bentuknya diciptakan oleh adisi dan substraksi dengan kemiringan yang mengikuti arah-arah mata angin. Material yang digunakan pada umumnya menggunakan beton dan kaca. Tekstur dan warnanya mengikuti karakteristik alami dari material yang digunakan.

\section{Langit- Openings}

langit Secara keseluruhan, batas yang menjadikan Wot Batu unik adalah batas atasnya yaitu langit. Tidak adanya batas fisik yang menyatukan langit-langit "ruangan" menghasilkan bangunan-bangunan kecil disertai dengan olahan lanskap. openings pada langit-langit Wot Batu memiliki dimensi yang sangat besar dengan bentuk yang ambigu. Bentuknya dapat dianggap geometris jika dipersepsikan dari batas-batas lain yang ada (seperti dinding dan lantai). Namun juga bisa dianggap organik jika menjadikan vegetasi (tajuk pohon) sebagai elemen pembatas.

Secara spesifik (boundaries within boundaries), Wot Batu memiliki dua bangunan dengan bukaan pada batas atasnya, yaitu pada 


\begin{tabular}{|l|l|}
\hline $\begin{array}{l}\text { musholla dan bangunan Batu Ruang. Bukaan pada kedua langit-langit } \\
\text { objek tersebut memiliki bentuk yang geometris, namun memiliki dimensi } \\
\text { dan susunan yang berbeda. Kedua bukaan tersebut dibatasi oleh material, } \\
\text { pada Musholla dibatasi oleh material glass block yang dilapisi lagi oleh } \\
\text { kaca buram, dan pada Batu Api menggunakan kaca transparan-kebiruan. }\end{array}$ \\
\hline
\end{tabular}

Tabel 2. Karakter pada Wot Batu

\begin{tabular}{|c|c|}
\hline \multicolumn{2}{|r|}{ Karakter (properti konkret) } \\
\hline Bentuk & $\begin{array}{l}\text { Bentuk-bentuk yang ada pada Wot Batu terlihat merata antara yang } \\
\text { geometris dan organik pada boundaries utama yang melingkup tapak, } \\
\text { ataupun boundaries within boundaries seperti bangunan-bangunan kecil di } \\
\text { dalamnya. Bentuk geometris yang dapat ditemukan misalnya pada: enclosure } \\
\text { dan openings dinding; enclosure dan openings langit-langit pada } \\
\text { boundaries within boundaries; openings lantai; dan enclosure lantai } \\
\text { boundaries within boundaries. } \\
\text { Bentuk organik misalnya pada: instalasi-instalasi batu; enclosure } \\
\text { lantai pada olahan lanskap; juga pada openings dinding utama dan openings } \\
\text { langit-langit utama jika menjadikan vegetasi sebagai elemen pembatas. }\end{array}$ \\
\hline Susunan & $\begin{array}{l}\text { Pada enclosure dinding Wot Batu, eksplorasi susunan yang dilakukan } \\
\text { umumnya adalah dengan memaju-mundurkan, dan memiringkan bidang } \\
\text { dengan arah-arah yang geometris (mengikuti arah angin). } \\
\text { Pada instalasi-instalasi batu, eksplorasi susunan yang dilakukan } \\
\text { misalkan dengan malayangkan batu (ditanam pada dinding atau kantilever), } \\
\text { seperti pada Instalasi Antara Bumi dan Langit, dan batu pada sudut selatan } \\
\text { Bale Batu; ditumpuk seperti pada Lawang Batu, Batu Air, dan Batu Sepuluh; } \\
\text { diberdirikan (vertikal) seperti pada Batu Abah, ditidurkan (horizontal) seperti } \\
\text { pada Batu Ambu dsb. } \\
\text { Wot Batu dapat dikatakan memiliki konfigurasi pola dasar memusat } \\
\text { karena adanya kolam sebagai titik tengah, dilanjutkan oleh jalur yang } \\
\text { mengelilinginya dan berbagai wilayah yang terbentuk pada sisi-sisinya. } \\
\text { Namun, pola dasar tersebut agak sulit dimengerti jika tidak dilihat dari denah. } \\
\text { Disamping itu, tidak menutup kemungkinan bahwa Wot Batu } \\
\text { sebenarnya memakai pola clustered. Karena jika ditinjau dari hasil } \\
\text { wawancara, dikatakan bahwa proses pengerjaannya "sangat organik". Walau } \\
\text { kemudian pengolahan lanskap menjadikan enclosure atau lingkup } \\
\text { pengelompokan-pengelompokan daerah lebih tegas dan jelas. }\end{array}$ \\
\hline Material & $\begin{array}{l}\text { Secara garis besar, enclosure yang ada pada Wot Batu umumnya } \\
\text { memakai material batu (batu kali lagadar, batu kapur padalarang, paving } \\
\text { andesit, paving block, batu sikat), beton, dan kaca. Semua material tersebut } \\
\text { juga mendukung tujuan Wot Batu untuk menjadi "catatan sebuah peradaban" } \\
\text { karena sifatnya yang kuat, dan tahan lama. }\end{array}$ \\
\hline Tekstur & $\begin{array}{l}\text { Tekstur secara umum tentunya mengikuti materialnya yaitu batu, } \\
\text { beton, dan kaca. Namun, tekstur dari material tersebut tidak semata-mata } \\
\text { seluruhnya dibiarkan, tetapi juga terdapat finishing atau tambahan yang } \\
\text { menjadikan suatu material yang sama memiliki tekstur dan warna berbeda. }\end{array}$ \\
\hline Warna & $\begin{array}{l}\text { Warna umum yang ada mengikuti karakteristik alami material batu, } \\
\text { berkisar antara gradasi hitam, putih, cokelat, kuning, dan merah; material kaca } \\
\text { yang transparan; dan vegetasi dengan warna hijau. }\end{array}$ \\
\hline
\end{tabular}


Pusat (centre) \& Jalur (path). sebagai bagian dari enclosure, pusat dan jalur juga terbentuk oleh adanya boundaries. Karena boundaries dapat dimengerti dalam tingkatan yang berbeda-beda, maka akan terbentuk beberapa pusat dan beberapa jalur. Di dalam Wot Batu, pusat utamanya diperkuat keberadaannya dengan langit sebagai boundary atas, jika ditarik garis secara diagonal dari sudut-sudut batas tapak untuk menentukan pusat, maka garis tersebut akan bersinggungan pada daerah kolam.

Berdasarkan boundaries yang terbentuk oleh adanya perbedaan tekstur (vegetasi dan perkerasan); pengangkatan permukaan dasar seperti pada dak beton Panggung Kehidupan yang menadahi Batu Indung, Batu Mandala, dan Batu Perahu; edge antara daratan dengan kolam; dan dengan didirikannya enclosure berupa dinding, path-pun terbentuk sebagai elemen pengisi di antaranya.

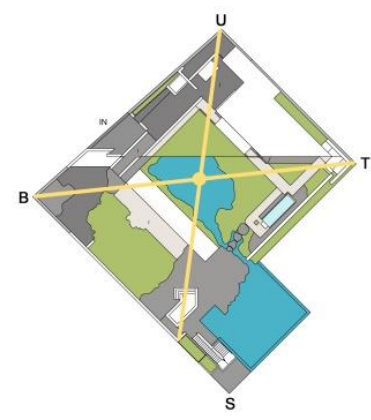

Figur 10. Pusat pada Wot Batu

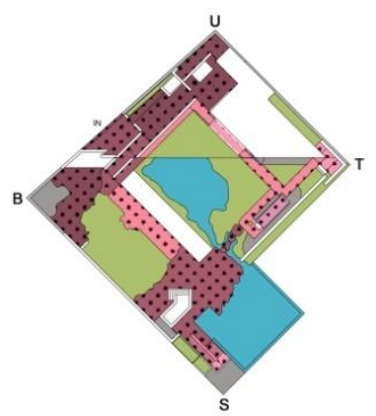

Figur 11. Jalur pada Wot Batu

Landmark. Landmark yang ada pada Wot Batu secara langsung ataupun secara tidak langsung dapat menciptakan atau memperkuat adanya suatu wilayah. "Tidak langsung" yang dimaksudkan adalah pengamat tidak menyadari wilayah secara eksplisit (langsung) dengan adanya boundaries berupa elemen konkret, tetapi wilayah dapat juga dirasakan melalui wilayah perseptual yang tercipta dari didirikannya suatu objek.

Contoh yang dapat diambil dari Wot Batu misalnya adalah bentuk dan karakteristik tiap-tiap instalasi batu yang unik memenuhi definisi landmark sebagai “objek pada lanskap yang mudah dikenali dari kejauhan sehingga memungkinkan seseorang untuk mengetahui lokasi". Karena itu, pengguna pada Wot Batu dapat mengenali bangunan atau instalasi sebagai penanda perbedaan wilayah, sehingga dapat muncul kalimat seperti, "di 'daerah' instalasi Batu Air", yang mengandung ide akan suatu batas dan penutup (boundary dan enclosure).

Kontribusi dari instalasi-instalasi pada Wot Batu dapat berfungsi sebagai landmark dan menjadikan tiap-tiap wilayah Wot Batu unik sehingga mudah dibedakan (imageabilitynya baik). Hal-hal yang dapat diidentifikasi sebagai landmark dalam Wot Batu diantaranya adalah:

a. Wilayah 2: Instalasi batu andesit Citatah sebagai penanda wilayah foyer (wilayah bagian luar bangunan loket tiket).

b. Wilayah 4: Instalasi Batu Abah sebagai landmark wilayah pada sudut barat (wilayah bagian luar bangunan musholla).

c. Wilayah 6: Batu Bumi sebagai landmark pada wilayah sisi barat daya.

d. Wilayah 7: Instalasi Batu Indung (yang paling terlihat dari jauh), Batu Parahu, dan Batu Mandala sebagai penanda wilayah Panggung Kehidupan. 
e. Wilayah 8: Instalasi Lawang Batu sebagai landmark perbatasan antara wilayah 6 dan wilayah 8 (wilayah sekitar instalasi Batu Api).

f. Wilayah 10: Instalasi Batu Air yang menandakan wilayah 10 yang berbatasan dengan daratan.

g. Wilayah 12: Instalasi Batu Sepuluh yang menandakan wilayah 12 (taman tengah) bagian tenggara, dan instalasi Batu Langit yang menandakan wilayah 12 bagian barat laut.

h. Wilayah 13: Pohon Kersen yang menandai wilayah sudut timur (wilayah pada sisi tenggara Bale Batu).

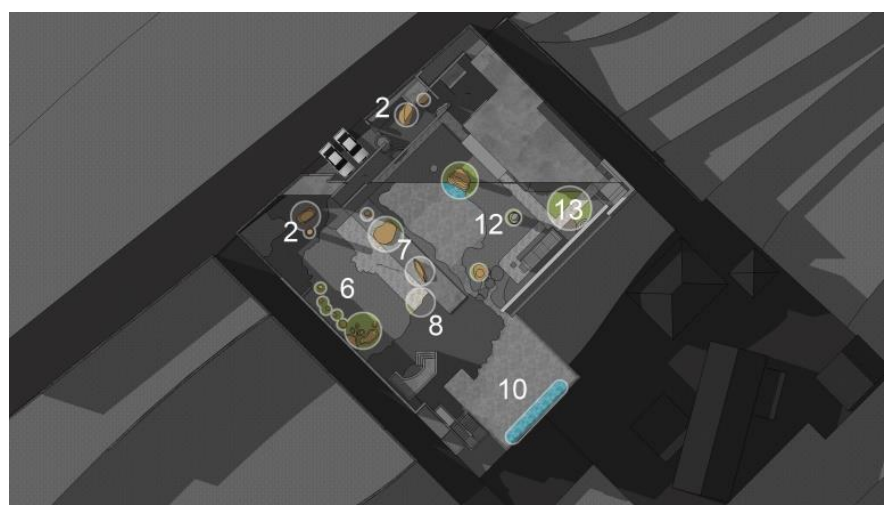

Figur 12. Struktur Tempat

Konfigurasi Pola Dasar (archetypal configuration). setelah menganalisis tentang "jalur" dan "wilayah" yang terbentuk dalam Wot Batu, dapat dimengerti bahwa tatanan spasial dalam Wot Batu terasa organik namun tersusun. Pola dasarnya dapat masuk dalam kategori memusat karena adanya kolam sebagai titik tengah, jalur yang mengelilinginya, dan berbagai enclosure lain yang terbentuk pada sisi-sisinya. Namun, pola dasar tersebut agak sulit dimengerti jika tidak dilihat dari denahnya, sehingga konfigurasinya bisa juga berjenis acak (clustered). Secara khusus organisasi yang digunakan juga masuk dalam pola spasial grid karena jalur-jalurnya yang ortogonal dan ruang-ruangnya yang sangat terbuka.

Sesuai hasil wawancara dengan pak Sunaryo, dikatakan bahwa pembangunan Wot Batu dilakukan secara organik, pengerjaan suatu instalasi sering kali menjadi parameter untuk menciptakan instalasi lainnya, dan banyak hal-hal yang terbangun tanpa rencana mengikuti intuisi atau perasaan. Pengerjaan yang dilakukan bertahap dari satu bagian tempat ke bagian tempat lainnya tanpa rencana (mengikuti denah gambar kerja, dsb.) sangat memungkinkan bahwa pada dasarnya Wot Batu memakai konfigurasi pola dasar jenis clustered. Walau kemudian pengolahan lanskap seperti taman dan perkerasan menjadikan enclosure atau lingkup pengelompokan-pengelompokan daerah yang lebih tegas dan jelas. 


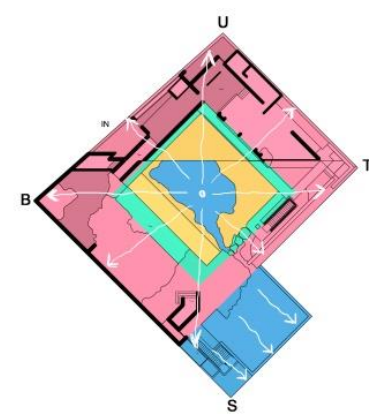

Figur 13. Konfigurasi memusat

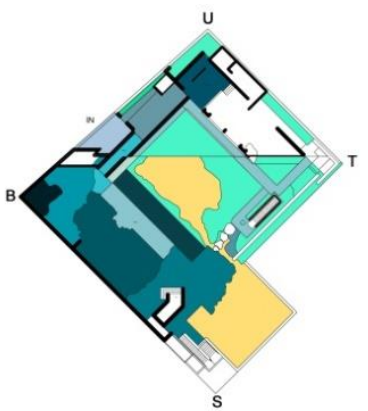

Figur 14. Konfigurasi cluster

Genius Loci pada Wot Batu. Di dalam Wot Batu, faktor-faktor pembentuk tempat yang ada (ruang dan karakter) memunculkan berbagai macam sifat, yaitu:

a. "dinamis dan hidup": Ditandai oleh Karakteristik yang beragam dan karena adanya openings yang sangat besar yang menghubungkan Wot Batu dengan langit sehingga cahaya dan hujan turut memperkaya karakteristik;

b. "bertujuan pada ekspresi": Ditandai oleh organisasi dan artikulasi yang tidak selalu berdasarkan fungsi;

c. "bentuknya yang tumbuh": Ditandai oleh tidak adanya pola ruang yang jelas; ruang-ruangnya dibentuk secara organik.

d. "penampilan yang luar biasa": Ditandai oleh dinding-dinding yang masif dan tinggi; banyaknya instalasi batu raksasa dan juga berbagai landmark.

e. "idilis (sangat indah)": Ditandai oleh keseimbangan antara elemen alami dan buatan; openings yang besar yang mengekspos bangunan kepada langit dan horison.

f. "intim": ditandai oleh dinding yang tinggi, lebar, dan masif yang menjadikan lingkungan ruang-dalam Wot Batu sangat terpisah dengan ruang-luarnya; hubungan antar wilayah pada ruang-dalam yang terbuka.

g. "misterius": ditandai oleh objek-objek dengan "bentuk" dan "susunan" yang tidak biasa.

h. "tatanan tersembunyi": ditandai oleh Adanya pusat dan elemen spasial yang terbentuk disekelilingnya; Adanya garis sumbu dengan kemiringan $45^{\circ}$ yang memotong tapak.

i. "bentuknya yang statis dan geometris": ditandai oleh enclosure dan openings pada dinding; enclosure dan openings pada langit-langit; openings pada lantai.

j. "pemberian identitas terhadap objek": ditandai oleh pemberian konsep; cerita; atau makna spiritual pada tiap-tiap instalasi, bangunan, hingga pembagian ruang.

Karena bukti-bukti tersebut Wot Batu dapat dikatakan masuk dalam kategori arsitektur kompleks. Singkatnya, Wot Batu dapat dikatakan didominasi oleh ciri-ciri arsitektur romantik baik umum ataupun khusus, namun juga mengandung sedikit ciri khusus "arsitektur kosmik" karena adanya tatanan spasial yang tersembunyi ditambah dengan bentuknya yang statis dan geometris, dan juga mengandung ciri umum "arsitektur klasik" karena adanya pemberian identitas terhadap elemen-elemen. Terdapat pada tabel 3 di bawah ini. 
Tabel 3. Tabel klasifikasi Genius Loci pada Wot Batu

\begin{tabular}{|c|c|c|c|}
\hline \multicolumn{4}{|c|}{ Genius Loci } \\
\hline & $\begin{array}{c}\text { Arsitektur } \\
\text { Romantik }\end{array}$ & Arsitektur Kosmik & Arsitektur Klasik \\
\hline Ciri umum & $\checkmark$ & - & $\checkmark$ \\
\hline $\begin{array}{c}\text { Ruang dan } \\
\text { Karakter }\end{array}$ & $\checkmark$ & $\checkmark$ & - \\
\hline Atmosfer & $\checkmark$ & - & - \\
\hline
\end{tabular}

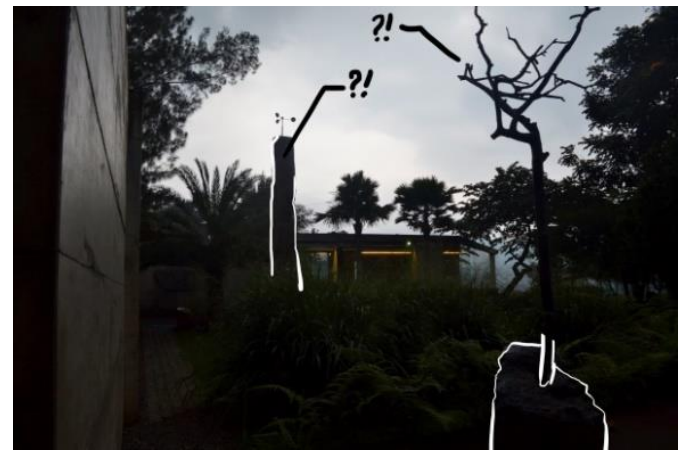

Figur 15. Wot Batu sebagai arsitektur romantik

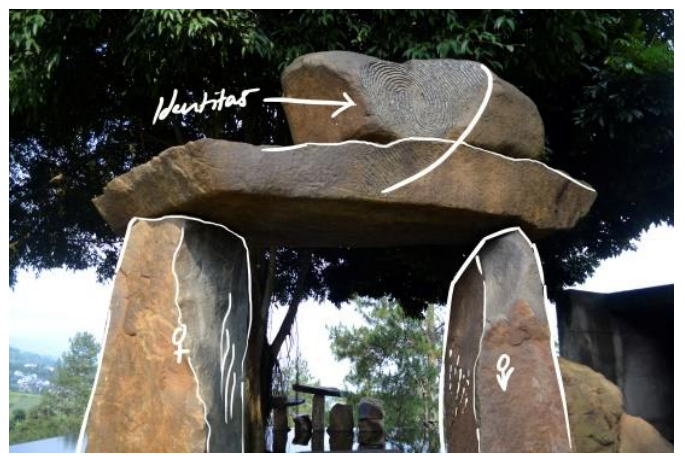

Figur 17. Wot Batu sebagai arsitektur klasik

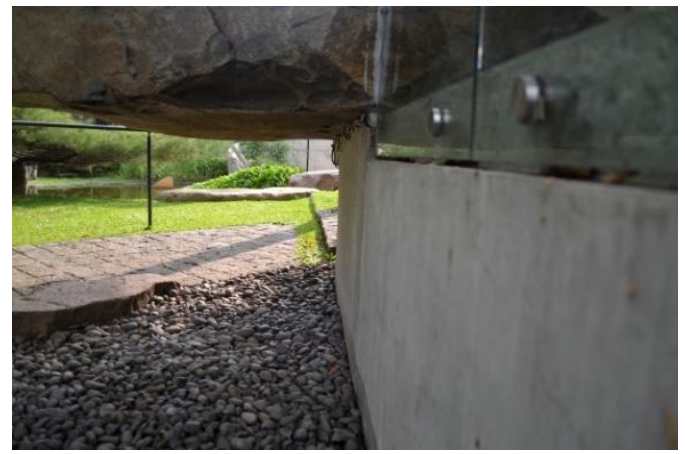

Figur 16. Wot Batu sebagai arsitektur kosmik

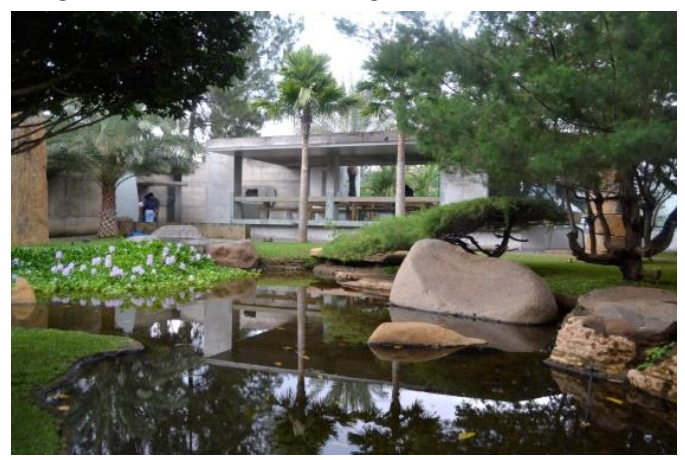

Figur 18. Wot Batu sebagai arsitektur kompleks

\section{KESIMPULAN}

Genius loci pada Wot Batu dibentuk oleh struktur spasial yang sangat variatif khususnya pada aspek bentuk dan susunan. Wot Batu memiliki bentuk geometris dan organik yang dapat dikatakan seimbang. Susunan dalam Wot Batu pada umumnya tidak memiliki pola khusus tertentu, kecuali pada kemiringan denah dinding yang mengikuti arah-arah mata angin.

Enclosure dan openings dari dinding, lantai, dan langit-langit yang ada pada Wot Batu baik secara umum (boundaries terluar) ataupun secara spesifik (boundaries within boundaries) berbeda-beda antara yang satu dengan yang lainnya. Karakteristik yang menjadi pemersatu pada Wot Batu ada pada penggunaan material batu, beton, dan kaca yang diikuti oleh tekstur dan warna alaminya masing-masing.

Genius loci yang terbentuk pada Wot Batu mencerminkan arsitektur kompleks dengan kecenderungan dominan terhadap ciri-ciri "arsitektur romantik" (baik umum ataupun khusus), namun juga mengandung sedikit ciri khusus "arsitektur kosmik" karena adanya 
tatanan spasial yang tersembunyi ditambah dengan bentuknya yang statis dan geometris, dan juga mengandung ciri umum "arsitektur klasik" karena adanya pemberian identitas terhadap elemen-elemen.

Saran. Bagi peneliti selanjutnya: diharapkan dapat melakukan penelitian dengan objek yang lebih bervariasi, misalkan dengan membahas objek pada lingkup yang lebih luas hingga skala kota, secara spesifik misalkan membahas tentang genius loci pada jalan tertentu, atau pada distrik tertentu. Sekilas, hal tersebut dapat terkesan mempersulit karena cakupan objek yang diperluas, namun kenyataannya belum tentu demikian.

Berikutnya, masih banyak fungsi objek penelitian lain yang dapat dihubungkan dengan genius loci. Tempat-tempat dengan atmosfer yang kuat sering kali diasosiasikan dengan bangunan-bangunan spiritual seperti tempat ibadah. Padahal semua tempat memiliki atmosfer spesifiknya masing-masing.

Bagi pembaca: setidaknya muncul kepekaan yang lebih mendalam untuk "melihat" suatu tempat yaitu melalui kesadaran akan "struktur spasial" yang menjadikan manusia dapat "mengorientasikan" diri dan struktur spasial tersebut diperkuat keberadaannya dengan diberikannya "properti konkret" sebagai pembentuk karakter yang menjadikan manusia dapat "mengidentifikasi" tempat.

Lalu, dengan pemahaman tersebut diharapkan agar pembaca mengerti tentang pentingnya atmosfer spesifik pada tiap-tiap tempat (khususnya pada arsitektur masa kini yang sering kali mengabaikan esensi genius loci) sebagai titik berangkat untuk penciptaan tempat yang lebih bermakna.

\section{DAFTAR PUSTAKA}

Norberg-Schulz, Christian. 1979. Genius Loci: Towards a phenomenology of Architecture. New York: Rizolli.

Relph, Edward. 1976. Place and Placelessness. New York: Van Nostrand Reinhold Company A Division of Litton Educational Publishing, Inc.

Tuan, Yi Fu. 1977. Space and Place. Minessota: University of Minessota Press. 